\title{
Tax Reforms and Evidence of Transfer Pricing
}

Deborah L. Swenson

Department of Economics

UC Davis and NBER

September 2000

Abstract: The manipulation of transfer prices changes the relative tax burdens multinational firms face in their different countries of operation and may even reduce a firm's worldwide tax payments. At the same time, transfer price manipulation will often trigger changes in the tariffs that are levied on intra-company imports. For this reason, when tax rates change, as they did for many countries during the 1980's, the incentive to manipulate transfer prices varies substantially across products. I use product-level variation in tariff duties to help me identify transfer pricing in products imported to the U.S. My empirical results indicate that reported customs values of U.S. imports from Canada, France, Germany, Japan and the U.K. were consistent with the transfer pricing incentives created by taxes and tariffs. While the results are statistically significant, they are economically small, implying that a 5 percent reduction in foreign corporate tax rates will cause the reported price of affiliated firm imports to rise by a mere $0.024 \%$. The meaning of these results and the implied value of transfer pricing penalties are explored.

Acknowledgements: I thank Robert Feenstra and Harry Grubert, Andrew Lee and Bob Lipsey for helpful discussions. Financial support from the IGCC of the Institute for Governmental Affairs is gratefully acknowledged.

Contact Information: Department of Economics, University of California, Davis, CA 95616. Phone (530) 752-1569, Fax (530) 752-9382. Email: deswenson@ucdavis.edu. 


\section{Introduction.}

While tax reforms have generally reduced corporate tax rates globally, continued international tax differentials are an enduring feature of the global fiscal environment. In this context, multinational firms can reduce their worldwide tax payments by shifting income from highly taxed jurisdictions to more lightly taxed locations. While income shifting can be accomplished through the reallocation of real activities, it can also be attained by shifting reported income, as occurs when firms manipulate their transfer prices on international transactions. While a few studies have examined transfer pricing directly, there is little evidence or consensus about the actual level of transfer pricing activities. ${ }^{1}$

Since research on tax incentives and the behavior of multinational firms typically relies on publicly available data, data limitations generally force researchers to focus on indirect evidence of income shifting. Most papers choose proxies such as reported income, tax payments, and intra-firm exports, and have found that cross-country and cross-time variations in these variables are consistent with income shifting incentives. ${ }^{2}$ Other work has shown that multinational firms have changed their real activities such as foreign investment, or altered their location of debt in response to tax incentives. ${ }^{3}$ However, while this line of research provides evidence from economic aggregates that is consistent with tax-induced income shifting, this line of research can not determine whether tax-induced transfer price manipulation played a major role.

This paper turns to individual product-level data to determine whether transfer-pricing incentives have played a significant and measurable role in the movement of U.S. import product prices. If firms use transfer prices to manipulate income, reported customs values should rise and fall with changes in tax incentives. I study the years 1981 to 1988 since they capture a period when the U.S. and many of its trade

$1 \quad$ Bernard and Weiner (1990) find little evidence of transfer pricing in the oil industry, while Jenkins and Wright (1975) come to the opposite conclusion. Since oil is a homogenous product when classified by grade, the scope for transfer pricing is reduced. Aside from oil, there are no empirical studies of transfer pricing at the product level.

2 Examples of this work includes Grubert and Mutti (1991) and Grubert, Goodspeed and Swenson (1993) Hines and Rice (1994) and Grubert (1997) which examine reported income, Harris, Morck, Slemrod, and Yeung (1993) which studies tax payments, and Grubert and Mutti (1991) and Clausing (1998) which investigate intra-firm trade flows.

3 Grubert and Mutti (1991), Hines and Rice (1994) and Hines (1996) find that taxes affect the location of firm 
partners changed their corporate tax rates. ${ }^{4}$ In general it is difficult to measure the effects of tax reform, since any year to year variation in aggregate data may be caused by changes in the underlying macroeconomic environment rather than changes in taxes. In this study I manage to avoid this problem, because I identify tax effects by examining fine product-level transfer prices in a framework that controls for corporate tax incentives, and cross-product tariff variation. The cost of shifting income out of the U.S. through artificially raised transfer prices differs across products according to U.S. tariff rates. I utilize these cross-product tariff differences to distinguish the responsiveness of reported transfer prices to transfer pricing incentives.

This paper proceeds as follows. In the next section, I explain how corporate taxes and product tariffs influence transfer-pricing incentives. I then develop a simple model that shows how multinational firms select their reported transfer prices based on tariff rates and tax considerations. In the third section, I use regression analysis to measure the response of product level prices to tariffs and taxes. In the fourth section I measure the implied penalties associated with transfer pricing and describe the economic implications of my results. A brief conclusion follows.

\section{Taxes, Tariffs and Income Shifting Incentives}

The foreign affiliates of multinationals commonly import goods from their parent firm. These imports arise because the affiliate acts as a distributor, or because the affiliate imports intermediate inputs from its foreign parent and assembles them in the host country. The discussion that follows assumes that firms base their production and sourcing decisions on market opportunities and relative production costs.

When multinationals set transfer prices for intra-firm transactions they may seek to maximize their expected world income by manipulating the reported transfer prices upward or downward. The direction of manipulation depends on the tax system governing the multinational, differences in tax rates between the home

investments. Altshuler, Grubert and Newlon (1997) echoes these findings, and suggests that the real effects of taxes have grown in recent years.

$4 \quad$ Grubert, Randolph and Rousslang (1996) document some of these trends in the 1980's. 
and affiliate locations, and any relevant product tariffs. ${ }^{5}$ When firms select a transfer price, they must consider the integrated effect of taxes and tariffs, since Internal Revenue Code Section 1059A states that the tax cost of imported goods is not to exceed their customs value. This effectively means that firms are required to select a single reported price for tax and tariff purposes.

To see how taxes and tariffs influence the firm's pricing decision, consider the tax linkages between a foreign parent firm and its U.S. affiliate. The firm can shift taxable income out of the US and in to its foreign parent country by reporting artificially elevated transfer prices. If the U.S. tax rate is higher than the tax rate in the home country, this strategy reduces the firm's worldwide tax payments since taxable income is transferred from the U.S. to the lower tax parent country. However, as the firm uses overstated transfer prices to shift income out of the U.S, it becomes liable for additional US tariff payments on the incremental elevation of transfer prices. If the tariff rate is especially high, all tax benefits associated with shifting may be more than offset by the new tariff payments. Further, income-shifting costs, penalties, and the fear of detection may all reduce the degree of transfer price manipulation selected by the firm.

Multinationals that are headquartered in high tax territorial countries face reverse tax incentives; they may decide to report artificially low transfer prices as a means of shifting income into the U.S. This is due to the fact that territorial firms pay taxes on income based on the location of earnings; income generated at home is taxed exclusively at home, while foreign earned income is taxed only abroad. ${ }^{6}$ As these firms reduce their worldwide tax payments, they enjoy the added bonus of lowered tariff payments that complement the strategy. I combine these ideas to create a simple model that describes how multinational firms set their transfer prices.

$5 \quad$ Tang (1993) p86. describes the results from a 1990 survey of 98 multinationals. Of twenty factors, these firms reported that their number two concern was "differentials in income tax rates and income tax legislation among countries", and that their number five concern was "rates of customs duties and customs legislation". When a different set of firms was surveyed in 1977 Tang reports that these same issues were ranked number four and number six on the same list of twenty issues.

6 Since firms located in high tax worldwide tax countries pay home taxes on all income earned, regardless of location, they will not benefit from transfer pricing manipulation that moves income to or from home. 


\section{A Model of Transfer Pricing Incentives}

Begin with a multinational firm that operates at home and has a single affiliate located abroad. ${ }^{7}$ The firm's economic return in the home and foreign countries is determined by its real decisions. The firm earns $\rho_{\mathrm{h}}$ on its home activities, and $\boldsymbol{\rho}_{\mathrm{f}}$ overseas. I assume that parent firm ships some parts, or completed products to its foreign affiliates for assembly and final sale. If the firm chooses transfer prices that reflect the arm'slength standard, the firm's real returns constitute the taxable income on which it pays taxes at home and abroad. However, if the firm manipulates its transfer prices, causing its reported transfer price $\mathbf{p}^{\mathbf{R}}$ to deviate from the arm's-length price $\mathbf{p}$ it alters its taxable income at home and abroad. ${ }^{8}$ While the firm may understate transfer prices, it will not choose a reported transfer price that is less than or equal to zero. Further, I assume that subsidiary income is sufficiently large that the tax benefit of transfer-price manipulation is not limited by the absence of subsidiary income to shift. Transfer pricing over- or under-statement is represented by a transfer-pricing margin:

$\delta_{h f}=\left(p^{R}-p\right)$

A positive value of $\delta_{\mathrm{hf}}$ indicates that the firm charges its affiliate a higher price for inputs than the arm's length price $\mathrm{p}$. When the firm overstates transfer prices, reported parent income rises at the expense of reported foreign affiliate income.

Transfer pricing decisions influence the firm's earnings in a number of ways. Since the transfer

$7 \quad$ The model incorporates features from Horst (1971), Eden (1986) and Hines and Rice (1994), though my analysis begins with some different assumptions. Horst argues that firm's transfer pricing decisions are constrained because customer arbitrage may arise if the multinational sets one price at home, and another abroad. In contrast, my model does not focus these firm limitations. I assume instead that international markets are segmented by informational barriers or transactions costs, and that firms prevent such customer arbitrage by using policies such as warranties that are valid only in the location of sale.

Hines and Rice (1994) focus on income shifting, in which income can be allocated from one affiliate to any other affiliate (or the parent) in the multinational's network. In contrast, transfer price manipulation is limited to country pairs for which intra-firm trade flows exist.

$8 \quad$ According to United Nations (1994), the OECD encourages countries to set guidelines that advise firms to use the Arm's Length Standard (ALS) in choosing their transfer prices. The ALS means that firms charge their subsidiaries the same price they would charge an unrelated party. Because comparable arm's-length transactions are often 
pricing term $\delta_{\text {hf }}$ represents the value of price overstatement per unit sold, the amount of income that is shifted depends on the volume of intra-firm imports $\mathbf{M}$ shipped from the parent firm to its affiliate. High transfer prices increase the parent firm's taxable home income by $\delta_{\mathrm{hf}} * \mathrm{M}$ and reduce taxable affiliate income by the same amount. ${ }^{9}$ Since high transfer prices also trigger increased tariff payments in the foreign country, a high transfer price causes the firm's taxable income in the foreign country to decline by the amount of its tariff payment, $\mathrm{TAR}_{\mathrm{f}} * \delta_{\mathrm{hf}} * \mathrm{M}$, where $\mathrm{TAR}_{\mathrm{f}}$ is the tariff rate.

When firms manipulate transfer prices, they are likely to face a number of costs. First, transfer price manipulation involves expenses related to design, including the hiring of consultants for advice. Later, if government authorities discover that the firm has manipulated its transfer prices, they may impose penalties on the firms. ${ }^{10}$ Finally, the system of tax investigation and conflict resolution may introduce uncertainty regarding the settlement of disputes. ${ }^{11}$ I introduce two penalty parameters $\mathbf{a}_{\mathbf{h}}$ and $\mathbf{a}_{\mathbf{f}}$, which represent the costs and penalties that are incurred at home and in the foreign country respectively. While it is possible that these penalties are small, I assume that they are strictly non-negative. I assume further that the penalty faced by the firm rises linearly with the volume of intra-firm imports, and that the penalty rises quadratically with magnitude of the reported price deviation. In part, this represents the idea that detection is unlikely for small price misstatements, but that the probability of detection increases as the transfer-pricing margin rises.

unavailable, the OECD guidelines, and U.S. Treasury regulations provide alternative methods for other transactions. 9 I assume that the physical quantity of intra-firm shipments is determined by real factors, such as production costs at home and abroad, and that the volume of intra-firm shipments is not affected by transfer pricing incentives. I also assume that transfer pricing affects only real transactions between the parent and its affiliate, or in other words, that firms do not record phantom intra-firm transactions on their corporate income tax returns.

10 Tang (1993) p21 reports that the IRS increased its number of examiners in the early 1990's by almost 100 to 582. Tang p20 also reports that a GAO survey of 519 multinationals in $1980 / 1981$ revealed that $60.1 \%$ of IRS adjustments (as measured as a percent of total dollar adjustments), represented pricing adjustments. In terms of dollar volumes, pricing adjustments were followed by adjustments to income allocation, expense allocation, intangibles, services, interest, rentals, and gain allocation.

11 In United Nations (1994), Plasschaert p13 writes that in the case of IRS adjustments and the actions of other tax authorities that "Trade channels accounted for the major percentage of the amounts adjusted, but the high frequency of disputes as regards interest payments is noteworthy. .... In the United States, about two dozen court cases have generated a considerable amount of legal writings. However, they do not provide much guidance, as they are complex and not easily replicable. .... The courts appear to favour "profit splits", thus accommodating the two countries involved instead of searching for the optimal transfer price. Most disputes were settled by compromise before they were submitted to (costly) court procedures. 
The multinational selects its transfer price margin $\delta_{\mathrm{hf}}$ to maximize its overall earnings $\mathbf{E}$, which comprise the after- tax value of the firm's earnings at home and the after-tax value of its earnings in the foreign affiliate.

$$
\underset{\delta}{\operatorname{Max}} E=\left(1-\tau_{h}\right)\left[\rho_{h}+\delta_{h f} M-\frac{a_{h}}{2} \frac{M\left(\delta_{h f}\right)^{2}}{p}\right]+\left(1-\tau_{a}\right)\left[\rho_{f}-\left(1+T A R_{f}\right) \delta_{h f} M-\frac{a_{f}}{2} \frac{M\left(\delta_{h f}\right)^{2}}{p}\right]
$$

The first set of terms in [ ] represent profits reported in the home country, all of which are subject to the home country rate of taxation $\tau_{\mathbf{h}}$, while the second set of terms in [ ] represents the profits reported in the foreign country. The tax rate that applies to affiliate profits, $\tau_{\mathbf{a}}$, depends on the form of taxation in the home country, and potentially on the relative corporate tax rates levied at home and abroad.

Firms headquartered in countries that use the territorial method of taxation, pay the host rate of tax on income that is earned abroad in their affiliates. Territorial firms do not pay home taxes for their activities conducted abroad. In contrast, worldwide investors are subject to home tax on their income earned in all locations, including the income generated by their foreign affiliates. To account for the taxes paid to host governments, firms located in worldwide locations are typically allowed to take a credit for taxes paid abroad, up to the rate of tax they owe at home. Effectively, the rate of taxation associated with a worldwide investor's foreign operations is the maximum of the home and host country tax rates. If host country taxes are higher than those of the home country, it is the host rate of taxation that applies to the multinational's affiliate earnings.

For territorial investors, and residential investors whose corporate tax rate at home is lower than that in the host, the affiliate pays the tax rate that is levied by the foreign host country, $\tau_{\mathrm{a}}=\left[\tau_{\mathrm{f}}\right]{ }^{12}$ Earnings maximization dictates that these firms choose the transfer-pricing margin:

$$
\delta_{h f}=\frac{\left[\left(\tau_{f}-\tau_{h}\right)-T A R_{f}\left(1-\tau_{f}\right)\right] p}{a_{h}\left(1-\tau_{h}\right)+a_{f}\left(1-\tau_{f}\right)} .
$$

12 In this project $\tau_{\mathrm{f}}$ is the U.S. corporate tax rate, as I am examining the activity of multinational firms with U.S. subsidiaries. 
Rewriting the expression and using the definition of the transfer pricing margin $\delta_{\mathrm{hf}}$, the resulting transfer price reported by the firm is:

$$
p^{R}=p\left[1+\frac{\left(\tau_{f}-\tau_{h}\right)-T A R_{f}\left(1-\tau_{f}\right)}{a_{h}\left(1-\tau_{h}\right)+a_{f}\left(1-\tau_{f}\right)}\right]
$$

The formula shows that the reported transfer price is equal to the arm's length price $\mathrm{p}$, plus a margin. Whether firms overstate or understate their transfer prices, relative to the arms-length price, depends on the size of tariffs, and cross-country tax differentials. In essence, the firm compares the benefit of shifting income out of the host country, which depends on the difference in the two country's tax rates, $\left(\tau_{\mathrm{f}}-\tau_{\mathrm{h}}\right)$, with the after-tax cost of tariffs TAR $\left(1-T_{f}\right)$, which is the price of shifting income out of the host country. The firm chooses to overstate transfer prices when the after-tax tariff cost is smaller than the tax benefits gained by relocating income to the more lightly taxed home. The numerator in the margin formula is the composite of these tax and tariff elements, or the transfer pricing incentive $(\mathbf{T P I})$; TPI $=\left\{\left(\tau_{\mathrm{f}}-\tau_{\mathrm{h}}\right)-\mathrm{TAR}_{\mathrm{f}}\left(1-\tau_{\mathrm{f}}\right)\right\}$. The transfer pricing incentive defines how much the multinational's income will rise, or fall, when the firm overstates its transfer price by one dollar. If the TPI is positive, the firm can enhance its worldwide income by overstating its transfer prices. For example, if the transfer pricing incentive is 0.11 , this indicates that the firm's worldwide income will rise by 11 cents for each dollar of transfer price overstatement. Conversely, if the TPI is negative, the firm raises its income by understating its reported transfer prices. In some cases the TPI is 0 , as it will be when the home and foreign tax rates are identical, and no tariffs are levied. When the TPI is 0 , there is no incentive to shift income in to, or out of the host country. While taxes and tariffs determine the predicted direction of transfer price manipulation, the degree of transfer price over- or understatement is mediated by the penalties facing the firm. If the penalties are high, or if detection is likely (as proxied by high values of $a_{h}$ and $a_{f}$ ), the responsiveness of reported prices will be small.

The decision framework for multinationals headquartered in high tax residential locations (e.g.: $\tau_{\mathrm{h}}>$ 
$\left.\tau_{\mathrm{f}}\right)$ is modified only slightly. The affiliate tax term $\tau_{\mathrm{a}}$ in the worldwide earnings function is now replaced with

$\tau_{\mathrm{h}}$. This implies that the home rate of corporate tax applies to all income earned by the multinational. The optimal transfer-pricing margin for these firms becomes:

$$
\delta_{h f}=-T A R_{f}\left(\frac{p}{a_{h}+a_{f}}\right)
$$

Rearranging the margin function and using the definition of the transfer pricing margin $\delta_{\mathrm{hf}}$, implies that the firm maximizes its profits when its reported transfer price is:

$$
p^{R}=p\left[1-T A R_{f}\left(\frac{1}{a_{h}+a_{f}}\right)\right]
$$

For these firms, the reported price coincides with the arm's-length price if the host country levies no tariffs on items shipped from the parent to the affiliate. However, when tariffs are levied, the firm can increase its overall earnings by reporting a transfer price that is less than the arm's-length price. Again, the actual responsiveness of reported prices depends on the penalties associated with transfer price manipulation.

The underlying message of this model is that reported transfer prices are a function of the comparable arm's-length price, the costs of avoidance, and a tax factor that combines corporate tax rates, applicable tariffs and the features of the home country tax system. While taxes and tariffs determine the magnitude and direction of incentives for transfer price manipulation, transfer price penalties and costs attenuate the actual degree of tax-induced transfer price manipulation.

In reduced form, a firm's reported price can be represented as a function of the arm's length price $\mathrm{p}_{\text {it }}$ and a function for the product price over- or understatement that depends on the transfer pricing incentive (TPI) and any relevant penalties or costs of transfer pricing. The basic implication of the model is that transfer price overstatement will increase as the TPI rises.

$$
p_{i t}^{R}=p_{i t} * f\left(T P I_{i t} ; a\right)
$$

In the next section I use this general formula to test the implications of the model. However, to check whether 
reported transfer prices correspond with transfer pricing incentives, I first examine overall summary statistics, before moving to a more detailed regression analysis.

\section{Empirical Evidence of Transfer Pricing}

While the transfer-pricing hypothesis is straightforward, there is little empirical evidence to quantify the economic importance of this method of income shifting in firm activities. To fill the void, I study the prices of U.S. imports from Canada, France, Germany, Japan, and the U.K. since these countries were some of the biggest foreign investors in the U.S., and their activity created an infrastructure of parent firms and U.S. affiliates which could manipulate transfer prices. Ideally, I would study the reported prices for individual firm intra-firm product sales. Since such data are not available, I am instead studying reported product prices by country. The sample covers 1981 to 1988 because these years involved frequent tax changes in the U.S. and abroad and cover years when U.S. tariff rates were changing. ${ }^{13}$

The fundamental price variable in the data set is based on U.S. Department of Census trade data collected at the fine TSUSA product-level. The TSUSA category system, or Tariff Schedule of the United States Annotated, is used to classify products for tariff purposes - all products within a particular TSUSA category face the same tariff rate. While the Census data do not report prices, they do report the annual value of imports for each TSUSA item by country, and the corresponding annual quantities of these imports. As a result, I construct reported prices by the formula $\mathrm{P}^{\mathrm{R}}{ }_{\text {ic }}=[$ (Custom's Value of Product i imports from country c)/(quantity of product i imported from country c)].

The identification of transfer pricing is based on the TPI variable. As is demonstrated in the previous section, the definition of the TPI is, TPI $=\left(\tau_{\mathrm{f}}-\tau_{\mathrm{h}}\right)-\mathrm{TAR}_{\mathrm{f}}\left(1-\tau_{\mathrm{f}}\right)$ if the investor is headquartered in a territorial country, or for investors headquartered in a residential country whose rate of tax is less than or equal to the

13 Grubert, Randolph and Rousslang (1996) describe the general downward trends in tax rates, and some of the changes in distribution. I end the sample with 1988, since the custom's method of classifying products changed in 1989 when the use of the Tariff Schedule of the U.S.A. (TSUSA codes) was replaced by the Harmonized System (HS) for product classification. 
U.S. corporate tax rate. For all other residential investors, the TPI $=-\mathrm{TAR}_{\mathrm{f}}$. In sum, the relevant TPI depends on the form of taxation in the multinational's home country, and on tax rates in the U.S. and the multinational's headquarters location.

Table 1 provides summary statistics on the tax and tariffs applied to the products in my sample. The median product in the sample entered the U.S. under conditions where the U.S. tax rate was $4 \%$ lower than the foreign tax rate. Tax conditions alone suggest that firms should shift taxable income away from the high tax parent locations and into the U.S. The tax goal of shifting income by underreporting transfer prices of products shipped to the U.S. would be bolstered by the desire to avoid the median product tariff of 4.2 percent. For the vast majority of products in the sample, the mean TPI suggests that firms had an incentive to underreport their U.S. transfer prices. However, the TPI is positive for a number of country product-year observations. I use time variation of the transfer pricing incentive to identify the responsiveness of reported transfer prices. Information on other control variables and fuller details regarding the sample creation are contained in the data appendix.

Two types of policy changes make the 1980's an ideal time to look for evidence of transfer price manipulation, since both create variation in the transfer pricing incentive variable. First, on the tax front, both the U.S. and foreign countries implemented tax reforms that reduced corporate tax rates. In the U.S., the Tax Reform Act of 1986 caused the U.S. corporate tax rate to decline first from 46 to 40 percent in 1987, and then from 40 to 34 percent in 1988. During the period of analysis, corporate tax rates also declined in Britain, Canada and France. The other policy change that affected TPI's during the period of estimation was the implementation of the Tokyo Round of GATT tariff cuts. The average product tariff rate in the sample was 5.98 percent in 1981, and declined to 3.81 percent in 1988, representing average annual tariff declines of .3 percent per year. ${ }^{14}$ Due to the frequent annual changes in national tax rates, and changing product tariff rates, I expect to gain identification of price changes related to changes in the TPI terms.

14 Tokyo Round Tariff reductions were implemented gradually between 1980 and 1986, rather than in a single year. Weighted by the custom's value of U.S. imports, the average tariff rate for the sample declined from 4.23 
As a preliminary check of my hypothesis, I first display the correlation between product price movements and changes in transfer pricing incentives in Figure 1. In particular, I examine how percentage changes in product prices $\left[\left(\mathrm{P}_{-} \mathrm{P}_{-1}\right) / \mathrm{P}_{-1}\right]$ are related to changes in the transfer pricing incentive. Since there are many other factors that cause general price changes, including exchange rate movements, changes in GDP, or quality changes, I first purge the price data of common country-year effects. ${ }^{15}$ For each country I display two columns. The first column +DTPI shows the average percentage change for reported prices, for those product-years where the transfer-pricing incentive increased. My hypothesis predicts that transfer prices rise when the transfer pricing incentive increases. The second column for each country, which is labeled -DTPI, shows the average percentage change in reported product prices for the product-years in which the transferpricing incentive fell. Notably, every column corresponds with the predicted direction of change. Reported product prices rose when the transfer pricing incentive increased, and declined when it fell. ${ }^{16}$

To formally investigate the link between reported transfer prices and transfer pricing incentives, I turn to regression analysis. The basic argument in the previous section demonstrates that transfer prices selected by profit maximizing multinational firms should rise along with transfer pricing incentives. To examine this hypothesis, I form the following estimating equation:

$$
P_{i c t}{ }^{R}=\alpha+\beta_{1} \text { Transfer PricingIncentive }{ }_{i c t}+\beta_{2}(G D P / C A P)_{c t}+{ }_{t} \gamma_{t}+{ }_{c} \lambda_{c}+\mathcal{E}
$$

The dependent variable is the reported transfer price $\mathrm{P}^{\mathrm{R}}$. The subscripts on the transfer price variable

percent in 1981 to 1.84 percent in 1988 .

15 To transform the data, I first regressed the initial data set of raw percentage price changes on a set of 39 individual country-year dummies, as the data set includes 5 countries over 8 years. I then subtract the common countryyear effects from the raw percentage price change data. Figure 1 displays the transformed percentage price change data. 16 While none of the columns is individually significant, a statistically significant relationship between price changes and changes in the transfer pricing incentive emerges in the full sample. For example, regressing the percentage price change on a dummy variable for TPI reductions, -DTPI, and a dummy variable for no change in TPI (the dummy variable for +DTPI is the omitted category), yields a coefficient of -.091 on the -DTPI variable with a standard error of (.020), and a coefficient of -.011(.030) on the no change dummy variable. The overall $\mathrm{R}^{2}$ for this regression is .0152 . Regressing the percentage price changes on the actual changes in the transfer pricing incentive yields a higher $\mathrm{R}^{2}$ of 
are $\mathrm{i}$ for product, $\mathrm{c}$ for country and $\mathrm{t}$ for year. The coefficient $\beta_{1}$ on Transfer Pricing Incentive is my variable of interest, as it tests for the presence of price changes related to tax incentives. Since prices may change in a systematic fashion across years due to the business cycle and other factors correlated with time, I include year dummies $\gamma_{t}$ to capture general time-based effects. To control for measurable cross country quality differences I introduce the variable $(\mathrm{GDP} / \mathrm{CAP})_{\mathrm{ct}}$, which is country gross domestic product per capita. I also include a set of country dummy variables $\lambda_{c}$ to control for other systematic cross-country differences, including those caused by unmeasured quality differences, international differences in market structure, or distance of a physical or cultural nature. Finally, to control for heteroskedasticity, I transformed all the variables in my estimating equation, including the country dummies, by dividing the regressor and independent variables by the square root of average reported prices.

I report my regression results in Table 2. In the full sample, the positive and significant coefficient on the transfer price incentive variable supports the model predictions regarding firm responses to changing transfer pricing incentives. Nonetheless, while the coefficient is precisely estimated, it is economically small. It suggests, for example, that a multinational headquartered in a territorial country will seek to remove taxable income from the U.S. by increasing its reported transfer price by .008 percent when home corporate tax rates fall by 5 percent. ${ }^{17}$ One reason why the implied response may not be larger is that the full data set includes trade that is transacted between multinational parents and their affiliates, as well as unaffiliated trade. It is unfortunate that the two can not be separated, since there is no reason to believe that prices associated with unaffiliated trade will deviate from the arm's-length standard, or that they will exhibit any correlation with changes in transfer pricing incentives. However, if the sample composition is similar to the composition of overall trade flows, one-third of trade transactions involve trade conducted between parent firms and their affiliates, and meets the criteria for this project. Assuming that the estimated tax term is based solely on the

.0231. In this regression, the coefficient of on the transfer pricing incentive is 3.685(0.743).

17 Since the regression is estimated in levels, the estimated response is evaluated at the sample mean.

This example also applies to multinational firms headquartered in a residential tax country whose tax rate is initially less than or equal to the U.S. corporate tax rate. 
behavior of parent firms and their affiliates, the coefficient estimates imply that a $5 \%$ reduction in foreign corporate taxes will cause the reported transfer prices for affiliated firms to rise by $0.024 \% .^{18}$

The estimated coefficients suggest that the enactment of TRA '86 had an even larger effect on transfer prices. This is because changes in U.S. tax rates have a single direct effect on the TPI for territorial firms or low tax residential firms. In contrast, when foreign tax rates increase, two offsetting effects are created: while the incentive to relocate income in the U.S. rises, this process reduces the amount of tariff payments it can deduct. Again, evaluated for the mean change, the overall coefficient reported in Table 2 suggests that the implementation of TRA '86 caused firms to report transfer prices for affiliated firms to decline by $0.066 \%{ }^{19}$

My estimate of transfer pricing responsiveness should be regarded as a lower bound for two reasons. First, if there is any omitted variable bias caused by correlation between the transfer pricing incentive which is my regressor, and the costs associated with transfer pricing, which are not formally included in this specification, then the coefficient on the transfer pricing incentive will be biased downward. If the true specification included a transfer pricing cost variable, and the coefficient on this variable were $\beta_{\text {cost }}$ then the omitted variable bias would be $\beta_{\operatorname{cost}} *\left\{[\operatorname{cov}(\right.$ TPI,TPI Cost) $] / \operatorname{Var}(\mathrm{TPI})\}$. Since $\beta_{\text {cost }}$ should be negative, and any covariance between TPI and the costs of transfer price manipulation is likely to be positive, the overall bias leads to an underestimate of the true transfer-pricing responsiveness term $\beta_{1}$. A positive covariance between the TPI and the cost of transfer price manipulation is expected, as we may imagine that firms will be especially likely to pay accounting firms to assist them in manipulating transfer prices when the transfer pricing incentive is abnormally large. Unfortunately, it is not possible to determine whether this form of omitted variable bias is present, as there are no good product-level measures for the costs of transfer price

18 Some of the intra-firm trade includes imports of U.S. parent firms from their foreign affiliates. For U.S. parent firm imports from Canada, France and Germany, the transfer-pricing incentives coincide with the incentives of parent firms and their U.S. affiliates. For U.S. imports from worldwide taxation Japan and the U.K., the incentives coincide in the years that U.S. tax is levied at a higher rate than taxes collected in the worldwide countries. If the years where U.S. parent firm incentives are different are dropped from the sample, the basic estimates do not change significantly. 19 As before, this assumes that the measured tax response is caused solely by the behavior of parent firms and their affiliates. 
manipulation. The second reason why I suspect the transfer-pricing coefficient is a lower bound relates to the calculation of transfer-pricing incentives. I use statutory tax rates, rather than marginal tax rates, to calculate the TPI, since it is not possible to measure the marginal tax rates that apply to products in my sample. Nonetheless, if there is any divergence of marginal tax rates from the statutory rates, then my transfer pricing incentives are measured with some error, and this will introduce a downward bias to my estimated transfer pricing incentive coefficients.

The full sample estimates assume that the level of penalties, and any transfer pricing costs are uniform across industries. This assumption will not hold if the probability of detection varies across industries, or if the scope for transfer pricing differs across products. If penalties and costs of transfer differ across industries, the model shows that the response to transfer pricing incentives will be smallest in those industries that face the greatest transfer-pricing impediments. To see whether industry responses differ meaningfully, I applied the basic estimating equation to individual products, estimating the TPI coefficient for products grouped industry by industry. A maintained assumption of this analysis is that the treatment of products within an industry is more similar than the treatment of products across the full spectrum of industries. The remainder of table 2 displays the response of reported transaction values to changes in transfer pricing incentives, by industry. Overall, price changes in most industries are consistent with the predictions from my simple model of profit-maximizing transfer-pricing manipulation. Of the 18 industries in the sample, six industries exhibit a positive and significant co-movement with transfer pricing incentives, and another five have the predicted positive coefficients, though these estimates are not precisely estimated. Only one significant industry coefficient contradicts the transfer-pricing hypothesis provided by the model.

I calculated the implied pricing effects for the industries that have precisely estimated tax coefficients. As with the full sample calculations, I am assuming that affiliated trade represents one-third of transactions in each of these industries. Under those circumstances, the coefficient estimates predict that the same 5 percent reduction in the foreign corporate tax rate would cause firms with affiliated transactions to increase reported 
transfer prices by $2.53 \%$ in the audio sector, $5.72 \%$ in the automobile industry, $22.5 \%$ in the chemical industry, $3.61 \%$ in the computer industry, $2.30 \%$ in metal products and $5.22 \%$ in textiles.

It is possible that industry differences in the implied degree of transfer price manipulation are related to industry differences in the ease of transfer-price manipulation. Such differences may be correlated with the industry importance of intangible assets, since products that rely most heavily on intangible assets are less likely to have comparable arms-length standard transactions that anchor their transfer prices. In other words, where comparable transactions are scant or non-existent, the multinational is likely to have greater potential discretion over its choice of transfer price. Unfortunately it is difficult to measure intangible assets. To proxy intangible assets, I turned to data on capital investment per establishment and to value-added per $\$ 1,000$ as reported in Manufacturing Worldwide. In my study the chemical industry exhibits the greatest implied transfer-pricing responsiveness, and chemicals are at the top and second from the top in the rankings for the six comparison industries as ranked by capital investment, and value added. However, the correlation between these measures and transfer pricing responsiveness is miniscule once I extend the comparison across the six significant industries. ${ }^{20}$ While the presence of intangible assets may increase the scope for transfer pricing, my measures do not appear to accurately pinpoint the areas of greatest opportunity. ${ }^{21}$

\section{Transfer Pricing and Penalties.}

Since the benefits of transfer price manipulation are attenuated by potential costs of shifting, I explored whether transfer pricing costs and penalties explain the small economic magnitude of the transfer pricing estimates. To estimate the implicit magnitude of transfer pricing penalties and costs, I applied nonlinear least squares estimation techniques to the pricing formulas in section 2 which show that the reported

20 The correlation between the implied price response and capital investment is 0.35 , while the correlation between the implied price response and value-added per $\$ 1000$ is 0.016 .

21 While my measures hint at the importance of intangible assets at an industry level, there is no proof that those inputs traded most heavily are well characterized by the industry average. In addition, even within industries, there is likely to be great heterogeneity across products in the degree of intangible intensity. Since I can't provide information on intangibles-intensity at the product level, the industry comparison is likely to be too crude to accurately portray the 
price for each product, parent country and year (subscripts i, c, and t) will take the form:

$p_{i c t}^{R}=p_{i c t} * f\left(T P I_{i c t} ; a\right)$.

Since I can't measure comparable arm's-length prices $p_{\text {ict }}$ directly I need to impose some structure on the problem. For this reason, I examine relative prices of products shipped by different countries (h and $\mathrm{m})$. The new estimation structure is based on these relative prices through the following ratio:

$$
\frac{p_{i h t}^{R}}{p_{i m t}^{R}}=\frac{p_{i h t}}{p_{i m t}} * \frac{f\left(T P I_{i h t} ; a\right)}{f\left(T P I_{i m t} ; a\right)} .
$$

To implement this procedure, I assume that the price ratio for arm's length prices $\mathrm{p}_{\mathrm{iht}} / \mathrm{p}_{\mathrm{imt}}$ is determined by overall quality differences between countries, and by macroeconomic factors. This implies that I can proxy the ratio of arm's length prices for each country pair with the ratio of arm's length prices for all products sold. 22 The resulting estimating equation relates the ratio of reported prices to the average over all products ratio (by country-year pair), and the tax-tariff-penalty functions derived in section 2. I use non-linear least squares, since reported prices are a non-linear function of the tax, tariff and penalty components.

My initial estimation framework attempted to measure the implied value of the U.S. and foreign penalty parameters. However, while the system generates a positive estimate for the U.S. penalty, the average foreign penalty for all countries is not statistically defined. ${ }^{23}$ This led me to test whether foreign penalties for over- or under-statement of transfer prices are asymmetric. When multinationals manipulate transfer prices on products shipped to the U.S., they may potentially reduce home country tax payments, but they do not deprive their customs officials of tariff revenue. If foreign governments only care about manipulation that removes taxable income from their jurisdiction, the foreign penalty parameter is only relevant when the TPI

latitude for transfer price manipulation.

22 For each country-year pair, the analysis estimates an average price ratio for prices of all products sold by country $h$, relative to all products sold by country $\mathrm{m}$. Formally I assume that $\mathrm{p}_{\mathrm{iht}} / \mathrm{p}_{\mathrm{imt}}=\mathrm{p}_{\mathrm{ht}} / \mathrm{p}_{\mathrm{mt}}$ for all products $\mathrm{i}$.

In my empirical estimation I choose Japan as my reference country in the denominator of my price ratio analysis, as the choice of Japan maximizes the number of defined ratios. (E.g.: The ratio is not defined if there were no product $\mathrm{i}$, transactions by reference country $\mathrm{m}$.)

23 While the foreign penalty parameter is not identified, the estimated U.S. penalty parameter $0.277(.013)$ is virtually identical to the estimate presented for the full sample in Table 3 . In unreported regressions I attempted to 
suggests shifting income away from the home country. If so, the penalty parameter can constrained to be 0 in all cases where transfer pricing incentives favored shifting income back to the multinational's home country. However, the estimated foreign penalty parameter for the remaining transactions is still inestimable.

The inability to estimate a specific foreign penalty parameter may stem from one of a number of plausible problems. First, it is possible that foreign governments find it difficult to effectively police the transfer pricing decisions of their multinationals. If this is the case, the true foreign penalty parameter is zero. A second possibility is that I have yet to discover a functional form that closely captures the foreign costs and penalties of transfer price manipulation. If the estimated specification does not accurately capture the form of penalties and costs, then it is not possible to estimate the weight that firms place on the avoidance of foreign penalties. Timing issues may also cloud measurement of the foreign penalty parameter. Foreign subsidiaries in the U.S. must follow U.S. regulations that provide minimal control over the timing of their U.S. tax payments. In contrast, foreign firms have much greater discretion over the timing of their repatriations from the U.S. Since this is a firm level decision, I can not incorporate this idea in a fashion that can be applied to aggregate reported product prices. While the model assumes that foreign firms pay all foreign taxes on accrual, this is not universally true. Finally, there is the classic problem that arises when one uses statutory tax rates to represent taxes, when firm decisions are based on firm marginal tax rates that are invisible to the researcher. If U.S. tax rates are highly correlated with the taxes faced by subsidiaries in the U.S., but foreign tax rates are poor approximations for the tax rates faced by parent firms in their headquarters location, this aspect of the data will reduce our ability to accurately identify foreign penalty effects.

In Table 3, I focus on a specification that includes a U.S. penalty parameter, but no foreign penalty, since my framework is unable to identify foreign penalties at any level of precision. In the full sample the estimated U.S. penalty parameter is positive, indicating that firms respond as if there is a cost to transfer price manipulation. Because the price ratio data are noisy, I used two procedures to examine the effects of outliers. In column (2) of Table 3, I used weighted non-linear least squares, using the reported customs value as 
weights. ${ }^{24}$ This procedure gives a larger weight to the larger volume transactions, which are likely to have the least measurement error. In the last column called NLS no tails, I eliminated those price ratios that were at the top and bottom 5\% of the distribution. For the full sample, it doesn't matter how the data are estimated, as the estimated shifting cost/penalty parameter remains in the same rough range. When I turn to individual industries however, the method of treating outliers has more effect on the estimated parameters.

To interpret my results, I compute the transfer price manipulation that would accompany a $1 \%$ reduction in the foreign tax rate from $34 \%$ to $33 \%$. My calculation is based on a U.S. tax rate of $34 \%$, and a $4.2 \%$ tariff rate, as this is the tariff rate for the median product in the sample. Since the U.S. tax rate is always greater than or equal to the foreign tax rate, the results apply equally to territorial and residential firms. I use the full sample penalty parameter of 0.279 that is reported in column 1 of Table 3 . The estimates imply that this reduction in the foreign corporate tax rate will induce firms to raise reported U.S. transfer prices by $6.3 \%$. To provide a comparison I also computed the implied effects for the three industries that faced the highest implied penalties - audio/communications, automobiles, and metal working machinery in column 2 of Table 3. These industries had mean tariff rates of $4.72 \%, 4.38 \%$ and $4.78 \%$ respectively, and their implied pricing responses are $2.31 \%$ for audio/communications, $1.44 \%$ for automobiles, and $2.48 \%$ for metal working machinery. In each case, artificially raised transfer prices would allow multinationals to move taxable income from the U.S. to the now more lightly taxed foreign location. This estimate should be regarded as an upper bound. If multinationals are concerned about foreign penalties, even though I haven't identified them, then the change in reported transfer prices will be further attenuated by the avoidance of foreign penalties.

The continued absence of an identifiable foreign penalty parameter, motivated my testing of one final specification which allows for asymmetry in U.S. penalties, emphasizing the possibility that Customs and Treasury penalties are not equally likely, or equally punitive. In particular, it is possible that tax authorities may not detect transfer pricing unless transfer price manipulation is extreme. In contrast, since U.S. customs

24 I do not use quantities, such as weight, since there is no uniform quantity measure (number, pounds, yards, etc.) that can be applied to all products in the data set. 
officials can observe individual product flows, lower levels of manipulation may catch their attention. The new transfer pricing equation has two U.S. penalty parameters: the first parameter applies to the shifting of income in to the U.S. through low transfer prices, the second applies to the shifting of income out of the U.S. via high transfer prices. I assume that the former applies to products whose TPI favors the inbound shifting of income, while the latter applies to products whose TPI favors shipping income out. ${ }^{25}$ In the full sample, the estimated coefficient (standard error) is .212(.002) for underreporting, while it is undefined for overreporting. If I repeat this exercise on an industry basis, I identify penalty parameters for over and underreporting in the auto parts and appliance industries, while the remaining industries only have a single defined penalty parameter related to the underreporting of transfer prices. Taken together, these results suggest that the model is better at identifying the form of customs penalties, while it has difficulties capturing the form of tax penalties and costs. To resolve this issue, further work based on individual firm models and data sets are needed. In general, firms act as if there is a penalty associated with underreported transfer prices, but no penalty for over-reporting. Customs penalties are likely to drive the former, while tax penalties drive the latter. ${ }^{26}$ Even if firms moderate their shifting behavior when they are concerned about customs penalties, while remaining unconcerned about the costs of tax avoidance or the punishments associated with tax evasion, it would be incorrect to assume that tax movements have no effect on pricing decisions. The parameter estimates suggest that fears of customs penalties inhibit tax-induced income shifting. The tax environment still matters, however, since inter-country tax differentials create the incentives for income shifting and are an important component that influences the magnitude of transfer price misstatement.

25 As tax rates changed over time, a product could change category as the implied transfer-pricing incentive changed sign.

26 Even if there are no tariffs, firms may be reluctant to declare low transfer prices if they are concerned about the possibility of triggering an anti-dumping suit. 


\section{Conclusion}

This paper studies the reported transfer prices for a set of products imported into the U.S. from Canada, France, Germany, Japan and the U.K. between 1981 to 1988. Tariff variation across products creates incentives for the underpricing or overpricing of affiliated firm transactions that may either complement or detract from general tax-induced income shifting motives. In my examination of the data I discover that reported prices rise when the combined effect of taxes and tariffs provides an incentive for firms to overstate their prices. While the results are statistically significant, they are economically small, implying that a 5\% decline in foreign tax rates causes the reported price of affiliated firm imports to rise by $0.024 \%$. Because transfer price manipulation is predicated on the actual flows of goods among countries, this method of moving income may be more costly than other methods of income shifting. While the manipulation of intra-firm trade transfer prices represents one potential avenue for income shifting, my evidence from trade transaction prices suggests that the manipulation of product transfer prices is not generally responsible for large movements in reported income. 
Figure 1

\section{Changes in Transfer Pricing Incentives \& Changes in Transfer Prices}

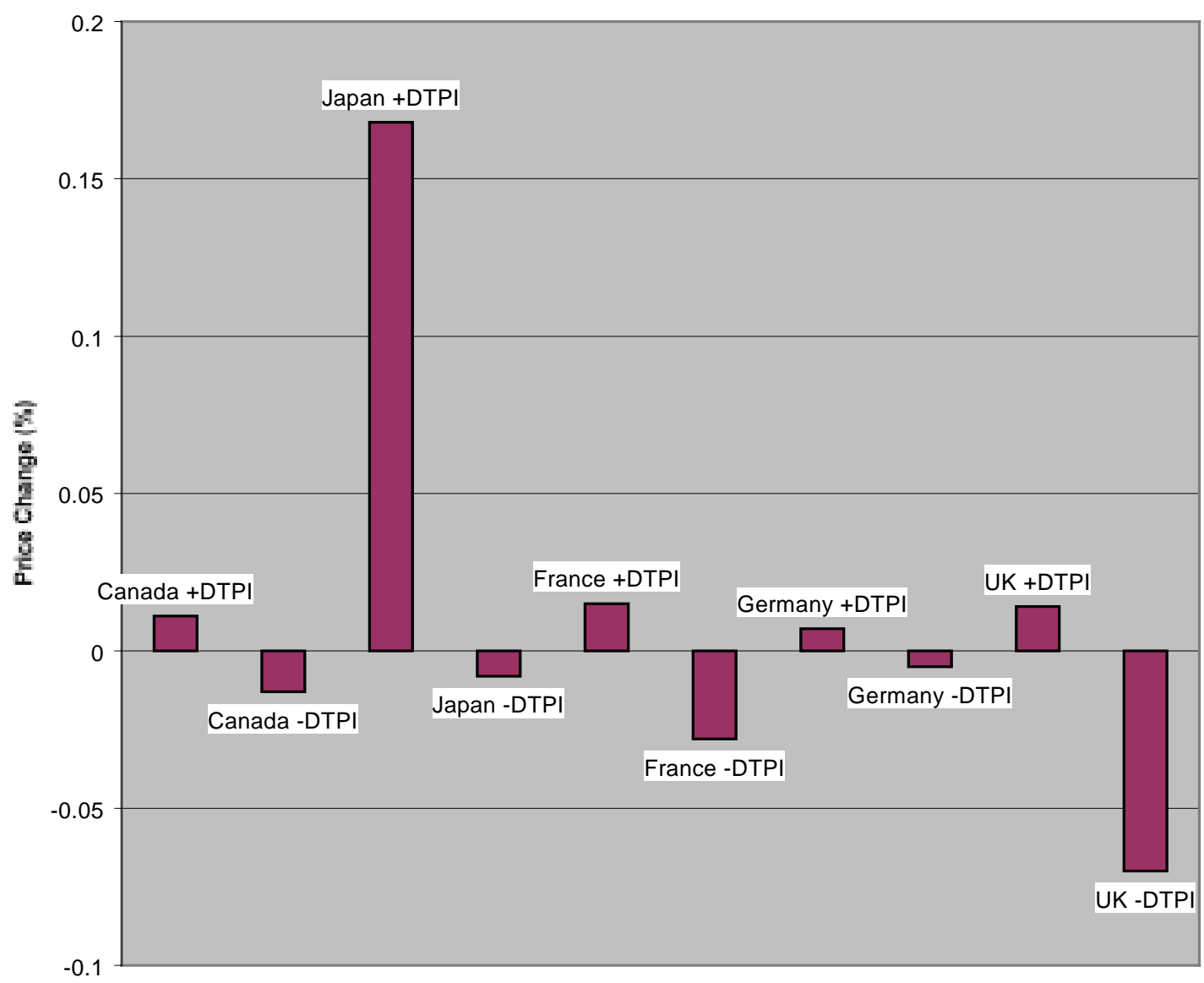

Notes: Each column displays average product price changes $\left[\left(\mathrm{P}_{-} \mathrm{P}_{-1}\right) / \mathrm{P}_{-1}\right]$ for products that faced changing Transfer Pricing Incentives (TPIs). The +DTPI columns measures the average for product years in which the TPI increased, while the -DTPI column measures the average for product years in which the TPI declined. As discussed in footnote 17, the reported price changes were first cleaned to remove common country-year price changes that affected all products in each country year. 


\begin{tabular}{|c|c|c|c|c|}
\hline Variable & Mean & $25^{\text {th }} P c t$ & Median & $75^{\text {th }} \mathrm{Pct}$ \\
\hline$\tau_{\mathrm{us}}-\tau_{\mathrm{f}}$ & $-3.4 \%$ & $-8.0 \%$ & $-4.0 \%$ & $1.0 \%$ \\
\hline Tariff Rate & $4.7 \%$ & $2.5 \%$ & $4.2 \%$ & $6.0 \%$ \\
\hline $\begin{array}{l}\text { Transfer Pricing } \\
\text { Incentive }\end{array}$ & $-6.1 \%$ & $-10.3 \%$ & $-6.0 \%$ & $-1.4 \%$ \\
\hline
\end{tabular}

Note: $\tau_{\text {us }}-\tau_{\mathrm{f}}$ is the difference between the U.S. and foreign rate of corporate tax. The Transfer Pricing Incentive is computed for a representative firm headquartered in a territorial taxation country $\left\{\mathrm{TPI}=\left(\tau_{\mathrm{f}}-\tau_{\mathrm{h}}\right)-\mathrm{TAR}_{\mathrm{f}}\left(1-\tau_{\mathrm{f}}\right)\right\}$, given the tax and tariff rates $\mathrm{TAR}_{\mathrm{f}}$ shown in each column. 
Table 2: Reported Unit Value Regressions: The Effect of Transfer Pricing Incentives. GLS Estimation.

\begin{tabular}{|c|c|c|c|c|}
\hline & $\begin{array}{l}\text { Transfer Pricing } \\
\text { Incentive }\end{array}$ & GDP per Capita & Obs & $\mathrm{R}^{2}$ \\
\hline Full Sample & $.108(.036)^{\mathrm{a}}$ & $.334(.061)^{\mathrm{a}}$ & 9384 & .033 \\
\hline Audio/Communications & $.732(.339) b$ & $1.16(.302)^{\mathrm{a}}$ & 467 & .24 \\
\hline Auto Parts & $3.76(11.2)$ & $66.7(13.1)^{\mathrm{a}}$ & 246 & .29 \\
\hline Automobiles & $24.8(10.3) \mathrm{b}$ & $-5.95(14.5)$ & 376 & .37 \\
\hline Beverages & $.001(.003)$ & $.022(.005)^{\mathrm{a}}$ & 497 & .59 \\
\hline Chemicals & $.020(.005)^{\mathrm{a}}$ & $0.015(.010)$ & 1131 & .09 \\
\hline Computers & $1.24(.715)^{c}$ & $.087(.952)$ & 403 & .26 \\
\hline Electronics & $-.008(.002)^{\mathrm{a}}$ & $.002(.005)$ & 744 & .23 \\
\hline Food & $-.0006(.0007)$ & $.004(.001)^{\mathrm{a}}$ & 272 & .26 \\
\hline Appliances & $.101(.112)$ & $.275(.289)$ & 395 & .14 \\
\hline Metal Products & $.003(.001)^{\mathrm{a}}$ & $-.017(.008)$ & 884 & .20 \\
\hline Metal Working Machinery & $6.723(7.71)$ & $-1.76(8.45)$ & 573 & .18 \\
\hline Office Equipment & $-.189(.194)$ & $.507(.276)^{\mathrm{a}}$ & 389 & .25 \\
\hline Pharmaceuticals & $.012(.012)$ & $-.026(.054)$ & 487 & .04 \\
\hline Plastics & $-.001(.002)$ & $.005(.003)^{\mathrm{c}}$ & 742 & .27 \\
\hline Rubber & $-.001(.007)$ & $-.002(.006)$ & 483 & .37 \\
\hline Industrial Machinery & $.232(.172)$ & $.056(.166)$ & 513 & .18 \\
\hline Textiles & $.017(.007)^{\mathrm{b}}$ & $-.007(.010)$ & 563 & .25 \\
\hline Transport Equipment & $-30.7(21.2)$ & $87.2(22.1)^{\mathrm{a}}$ & 219 & .25 \\
\hline
\end{tabular}

Notes: Standard errors in ( ). To perform GLS the dependent variable and all regressors were divided by the square root of average reported price by TSUSA product. Each regression includes a set of year and country dummy variables. Estimates marked ${ }^{a}$ are significant at the 1-percent level; those marked ${ }^{\mathrm{b}}$ are significant at the 5-percent level; and those marked ${ }^{\mathrm{c}}$ are significant at the 10percent level. Further details regarding data construction are contained in the data appendix. 
Table 3: Non-Linear Least Squares estimates of the U.S. Penalty Parameter.

\begin{tabular}{|c|c|c|c|c|c|}
\hline & NLS & WNLS & $\begin{array}{c}\text { NLS } \\
\text { No Tails }\end{array}$ & Obs1 & Obs2 \\
\hline Full Sample & $.279(.015)$ & $.226(.001)$ & $.277(.002)$ & 6598 & 5939 \\
\hline Audio/Communications & $.346(.109)$ & $.715(.425)$ & $.190(.008)$ & 360 & 286 \\
\hline Auto Parts & $.146(.015)$ & $.147(.021)$ & $.148(.007)$ & 143 & 117 \\
\hline Automobiles & $.332(.017)$ & $1.10(.594)$ & $.327(.013)$ & 205 & 184 \\
\hline Beverages & $.153(.005)$ & $.124(.003)$ & $.154(.005)$ & 284 & 283 \\
\hline Chemicals & $.263(.017)$ & $.249(.009)$ & $.253(.005)$ & 776 & 603 \\
\hline Computers & $.240(.027)$ & $.627(.243)$ & $.222(.015)$ & 314 & 279 \\
\hline Electronics & $.173(.005)$ & $.148(.004)$ & $.170(.004)$ & 590 & 538 \\
\hline Food & $.177(.015)$ & $.171(.004)$ & $.176(.010)$ & 138 & 111 \\
\hline Appliances & $.189(.062)$ & $.269(.201)$ & $.192(.005)$ & 303 & 254 \\
\hline Metal Products & $.188(.005)$ & $.177(.002)$ & $.183(.003)$ & 691 & 676 \\
\hline Metal Working Machinery & $.172(.003)$ & $.658(.192)$ & $.170(.005)$ & 427 & 376 \\
\hline Office Equipment & $.524(.363)$ & $.521(.177)$ & $.172(.008)$ & 290 & 264 \\
\hline Pharmaceuticals & $.238(.430)$ & $.222(.047)$ & $.234(.009)$ & 227 & 173 \\
\hline Plastics & $.174(.003)$ & $.197(.006)$ & $.173(.003)$ & 590 & 574 \\
\hline Rubber & $.150(.005)$ & $.145(.004)$ & $.149(.0005)$ & 341 & 329 \\
\hline Industrial Machinery & $.192(.006)$ & $.259(.017)$ & $.185(.006)$ & 386 & 368 \\
\hline Textiles & $.225(.002)$ & $.244(.008)$ & $.237(.003)$ & 426 & 421 \\
\hline Transport Equipment & $.176(.013)$ & $.178(.018)$ & $.173(.012)$ & 117 & 103 \\
\hline
\end{tabular}

Notes: Standard errors in ( ). NLS = non-linear least squares. WNLS is weighted non-linear least squares, using product the custom's value of import shipments as weights. NLS No Tails removes the price ratios in the positive and negative 5\% tails of the distribution. Obs1 lists the number of observations in regressions of the NLS and WNLS columns. Obs2 lists the number observations for the NLS No tails column. 


\section{Data Appendix}

The formation of my data set began with the selection of industries that had high levels of intra-firm trade, and for which the import propensity of foreign affiliates located in the U.S. exceeded the the import propensity of U.S. parent firms. ${ }^{27}$ I chose to study imports originating from Canada, France, Germany, Japan and the U.K. since these countries were responsible for a significant share of U.S. foreign direct investment activity. The following table reports establishments, employees and payroll for the countries in my sample, as well as the universe totals. On these three dimensions, no other country played as large a role in foreign investment activity as the countries in my sample. I focus on manufacturing, since manufacturing generates demand for imported intermediates from the parent firms.

Characteristics of Foreign Manufacturing Establishments, 1988.*

\begin{tabular}{lccc} 
Canada & $\begin{array}{l}\text { Establishments } \\
\text { (number) }\end{array}$ & $\begin{array}{l}\text { Employees } \\
\text { (number) }\end{array}$ & $\begin{array}{l}\text { Payroll } \\
(\$ 1,000 \text { ’s) }\end{array}$ \\
France & 1,098 & 240,814 & $7,481,274$ \\
Germany & 880 & 122,770 & $3,629,729$ \\
Japan & 807 & 190,496 & $6,121,111$ \\
United Kingdom & 920 & 169,594 & $5,262,520$ \\
\hline Total & 2,723 & 360,415 & $9,975,087$ \\
\hline
\end{tabular}

* Source: U.S. Department of Commerce, Economics and Statistics Administration. "Foreign Direct Investment in the United States: Establishment Data for Manufacturing, 1988". Table 1.7, p38.

The sample includes the years 1981 to 1988 since this time period was characterized by frequent changes in taxes by the U.S. and elsewhere. I end the study with 1988, since the custom's method for categorizing imported products changed in 1989.

Reported Prices $\left(\mathbf{P}^{\mathbf{R}}\right)$ : To construct reported prices for each product for the countries and years in the sample, I use data taken from the Tariffs Schedule of the United States Annotated (TSUSA) of the Department of Commerce, Bureau of the Census (1981-1988), and collected by Feenstra (1996). For each TSUSA product, these data report the Customs value of U.S. imports from each country, as well as the quantity of each TSUSA item imported. My reported price measure $\mathrm{P}^{\mathrm{R}}$ is formed by dividing the customs value of imports by quantity. $\mathrm{PR}_{\mathrm{ic}}=\left[\left(\right.\right.$ Custom's Value of Product ${ }_{\mathrm{i}}$ from country $\left.\mathrm{c}\right) /($ quantity of product $\mathrm{i}$ imported from country $\left.\mathrm{c})\right]$. Since the price measure is based on all of the product imports from the country, it represents the average reported price for all firms and transactions in the year. In other words, the trade data are a composite of all affiliated

27 I used information in Zeile (1998) Table 13 p49 to measure the relative importance of imported intermediate inputs for foreign affiliates, as compared with U.S. parent firms. For all manufacturing firms, the average reliance on imported intermediate inputs is 1.65 times larger for foreign affiliates than for U.S. parent firms in the same industry. 
firm transactions and non-affiliated firm transactions together.

Extreme outliers in the price data series were eliminated from the sample. Each year's price was compared with previous and future prices. If the price was substantially different than the previous and future prices it was deleted. My deletion mechanism was based on prices that had fallen by more than $71 \%$ from the previous year value, or had risen to more than 2.65 times its previous value.

Industry Classification: The industry groupings displayed in tables 2 and 3 are based on 5- SITC (Standard International Trade Classification) classifications. To place TSUSA products into 5-digit SITC groups, I used the TSUSA/SITC concordance provided by Feenstra (1996) in the trade data set.

Average Unit Value: $\left(\mathrm{P}_{\mathrm{i}}^{\mathrm{R}}\right)$ For each TSUSA product, average unit value was formed by taking the average of $\mathrm{P}^{\mathrm{R}}$ over all countries, and all years.

Transfer Pricing Incentive: I use the formulas for the transfer pricing incentive explained in section 2, and detailed in footnote 14 . TPI $=\left(\tau_{\mathrm{f}}-\tau_{\mathrm{h}}\right)-\mathrm{TAR}_{\mathrm{f}}\left(1-\tau_{\mathrm{f}}\right)$ if the investor is headquartered in a territorial country, or if the investor is headquartered in a residential country whose rate of tax is less than or equal to the host rate $\tau_{\mathrm{h}}$. For all other residential investors, TPI $=-\mathrm{TAR}_{\mathrm{f}}$. This combines country corporate tax rates reported in Cummins, Harris and Hassett (1995) with TSUSA product tariffs from the Bureau of Census (1981-1988) import data. The United Kingdom and Japan are classified as residential or worldwide tax countries, while Canada, France and Germany are classified as territorial tax countries. The non-linear least squares estimates are based on the formulas derived in section 3, which include a penalty parameter.

Gross Domestic Product per Capita: These data are taken from the International Monetary Fund's International Financial Statistics. 


\section{References}

Altshuler, Rosanne, Harry Grubert, and T. Scott Newlon (1997), "Has U.S. Investment Abroad Become More Sesitive to Tax Rates?" manuscript.

Bernard, Jean-Thomas and Robert J. Weiner, (1990), "Multinational Corporations, Transfer Prices, and Taxes: Evidence from the U.S. Petroleum Industry," in Assaf Razin and Joel Slemrod, eds., Taxation in the Global Economy, Chicago: The University of Chicago Press, 123-154.

Clausing, Kimberly A. "The Impact of Transfer Pricing on Intra-firm Trade," NBER Working Paper no.6688.

Cummins, Jason G. Harris, Trevor S. and Kevin A. Hassett. (1995), “Accounting Standards, Information Flow, and Firm Investment Behavior," in Feldstein, Hines and Hubbard eds., The Effects of Taxation on Multinational Corporations, Chicago: The University of Chicago Press, 181-221.

Eden, Lorraine. (1985), "The Microeconomics of Transfer Pricing," in Alan M. Rugman and L. Eden eds. Multinationals and Transfer Pricing. New York: St. Martin's, 13-46.

Feenstra, Robert C. (1996), “U.S. Imports, 1972-1994: Data and concordances,” NBER Working Paper \#5515.

Grubert, Harry, (1997), “Another Look at the Low Taxable Income of Foreign-Controlled Companies in the United States," manuscript.

Grubert, Harry, (1998), "Taxes and the division of foreign operating income among royalties, interest, dividends and retained earnings." Journal of Public Economics, 68(2): 269-290.

Grubert, Harry, Timothy Goodspeed and Deborah Swenson, (1993), "Explaining the Low Taxable Income of Foreign-Controlled Companies in the United States," in in Giovannini, Hubbard, and Slemrod, eds, Studies in International Taxation. Chicago: University of Chicago Press, 237-270.

Grubert, Harry and John Mutti (1991). "Taxes, Tariffs and Transfer Pricing in Multinational Corporation Decision Making." Review of Economics and Statistics. 17(2): 285-293.

Grubert, Harry, William C. Randolph and Donald J. Rousslang, (1996), "Country and Multinational Company Responses to the Tax Reform Act of 1986," National Tax Journal, V49(N3):341-358.

Harris, David, Randall Morck, Joel Slemrod, and Bernard Yeung. (1993). "Income Shifting in U.S. Multinational Corporations." in Giovannini, Hubbard, and Slemrod, eds, Studies in International Taxation. Chicago: University of Chicago Press, 277-302.

Hines, James R. Jr. (1996), "Altered States: Taxes and the location of foreign direct investment in America." American Economic Review, 86 (5):1076-1094.

Hines, James R. Jr. (1996), "Dividends and Profits, Some Unsubtle Foreign Influences," Journal of Finance, 51(2): 661-689. 
Hines, James R. Jr. and Eric M. Rice, (1994), "Fiscal Paradise: Foreign Tax Havens and American Business," Quarterly Journal of Economics, 109(1):149-181

Horst, Thomas. (1971). "The Theory of the Multinational Firm: Optimal Behavior Under Different Tariff and Tax Rates," Journal of Political Economy. 79(5): 1059-1072.

Kopits, George F. (1976). "Intra-firm Royalties Crossing Frontiers and Transfer Pricing Behavior." Economic Journal. 86:791-805.

Jenkins, Gordon P. and Brian D. Wright, (1975). "Taxation of Income of Multinational Corporations: The Case of the United States Petroleum Industry," Review of Economics and Statistics, 57(1):1-11.

Tang, Roger Y.W. (1993). Transfer Pricing in the 1990's: Tax and Management Perspectives. London: Quorum Books.

United Nations: Department of Economic and Social Development, Transnational Corporations and Management Division (1994). The United Nations Library on Transnational Corporations, Volume 14, Transnational Corporations: Transfer Pricing and Taxation Edited by Sylvain Plasschaert, General Editor, John H. Dunning. London: Routledge.

U.S. Imports for Consumption and General Imports, TSUSA Commodity by Country of Origin FT246, Bureau of the Census, Department of Commerce, Washington, D.C. 1981-1988.

Zeile, William J. (1998). “The Domestic Orientation of Production and Sales by U.S. Manufacturing Affiliates of Foreign Companies." Survey of Current Business, April, 29-50. 